\title{
フロー型セルを用いる微小部陽極酸化とその応用
}

\author{
坂入 正敏 ${ }^{\mathrm{a}}$, 班 映斎 ${ }^{\mathrm{b}}$, 松本 敏幸 ${ }^{\mathrm{b}}$ \\ a 北海道大学大学院工学研究院 ( $\bar{\top} 060-8628$ 北海道札幌市北区北 13 条西 8 丁目) \\ ${ }^{b}$ 北海道大学大学院工学院 ( $\bar{T}$ 060-8628 北海道札幌市北区北 13 条西 8 丁目)
}

\section{Local Anodizing by Solution Flow Type Micro-Droplet Cell and its Application}

\section{Masatoshi SAKAIRI a ${ }^{\text {, Yingi BAN }}{ }^{\text {b }}$ and Toshiyuki MATSUMOTO ${ }^{\mathrm{b}}$}

\author{
${ }^{a}$ Faculty of Engineering, Hokkaido University (Kita-13, Nishi-8, Kita-ku, Sapporo-shi, Hokkaido 060-8628) \\ ${ }^{\mathrm{b}}$ Graduate School of Engineering, Hokkaido University (Kita-13, Nishi-8, Kita-ku, Sapporo-shi, Hokkaido 060-8628)
}

Keywords : Localized Anodizing, Solution Flow Type Micro-Cell, Aluminum

\section{1. はじめに}

アルミニウムやチタニウムに陽極酸化によって形成できる 酸化物皮膜は, 大きく二種類に分けられる。一つは緻密型や バリヤー型と呼ばれる皮膜の厚さが, 形成時の電場に比例す

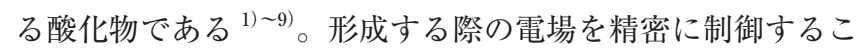
とで $\mathrm{nm}$ 程度の精度で制御可能である。アルミニウムのバリ ヤー型皮膜は, 電解コンデンサの誘電体として利用されてい る ${ }^{6)}$ 。もう一つは, 多孔質型やポーラス型と呼ばれ, 皮膜内 部に自己組織化による規則正しい孔とその底部にバリヤー層

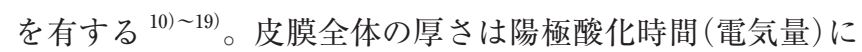
依存し, バリヤー層の厚さは電場に依存する。アルミニウム の場合, 古くからアルマイトして耐摩耗性や耐食性の向上の ために利用されてきた。近年は, その高い規則性から, 微細 構造体のモールドやメンブレンフィルター等にも利用されて

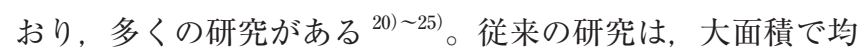
一に陽極酸化することに主眼がおかれていたが, 電子機器の 小型化などを考えると, 微小領域や形状を制御した陽極酸化 法が必要である。さらに, 材料には結晶粒や析出物などが存 在するため, その表面は不均一である。陽極酸化により形成 される酸化物皮膜への不均一性の影響を知ることは, 大面積 を対象とした陽極酸化にも重要と言える。

前述の表面不均一性による陽極酸化挙動への影響調査や微 小領域における陽極酸化は, 微小液滴セルを用いることで可 能となる。本稿で注目するは, 内径 $1 \mathrm{~mm}$ 以下の樹脂やガラ ス製のキャピラリ管を用いる電気化学セルである。キャピラ リ管を電気化学測定に利用することは古くから行われている。 例えば, キャピラリ先端に各種イオン選択膜を付与した微小 電極は電気化学センサーとして利用されている ${ }^{26)}$ 。ルギン (Luggin-Haber) 管を用い, セル中に二つの参照電極を設置し て片方の管先を試料表面上で走査することで試料表面近傍の 電位分布を測定している ${ }^{27)}$ 。キャピラリや微小電極を利用

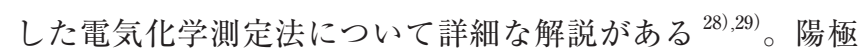

酸化や電気化学測定を目指したキャピラリを用いる微小液滴 セルは, 1990 年代後半にスイスの Böhni ${ }^{30)}$ とドイッの Lohrengel ${ }^{31)}$ の研究グループからほぼ同時期に発表され, キャ ピラリ管先端の構造に相違点はあるが, 装置構成や適用例に 共通点が多い。

本稿では, 微小液滴セルについて解説するとともに, その 応用例として著者らが研究している同軸 2 重管構造をもつ溶 液フロー型の微小電気化学セルを用いる局部陽極酸化につい て紹介する。

\section{2. 微小液滴セルについて}

本稿で注目しているキャピラリ管を用いる微小液滴セルの 模式図を図 1 に示す。図 1 のように(a)ガスケット型と (b) メ ニスカス型の構造に大別できる。図中のキャピラリ管は, 試 料電極表面に電解質溶液を供給するための管, 電解質溶液を 保持するセル構造の一部と試料表面の微小領域を電極として 限定するシールの三つの役割をになっている。キャピラリ管

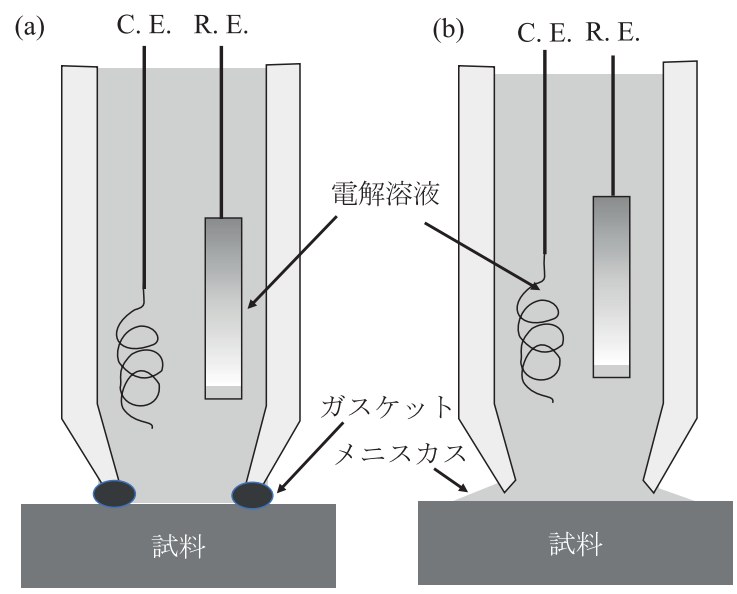

図 1 キャピラリ管を用いる微小液滴セルの模式図 (a) ガスケット型， (b) メニスカス型 
には，先に述べたガラスの他に石英，ポリエチレンやポリプ ロピレンなどの絶縁性の小径管が用いられる。キャピラリ管 に対極の機能も持たせる時には，導電性のある白金，金もし くはステンレス鋼製の小径管を用いることもある。ガラス製 の管は，局部を加熱・延伸・切断することにより，その主胴 部よりも十分に小径でサイズを制御した先端開口部を作製で きることから良く使用される。次に，溶液をフローさせない (溶液静止) ガスケット型とメニスカス型について述べた後, 溶液をフローさせるセルについて述べる。

\section{1 溶液静止型微小液滴セル}

ガスケット型微小液滴セルは, 図 1 (a)に示すようにキャ ピラリ管先端はガスケットを介して試料表面に接触している。 微小液滴セルはその接触している内側に形成される。ガス ケット内部の溶液に接している試料電極表面が電気化学測定 などの対象となる。この型では, キャピラリ管先端と試料表 面の間から電解質溶液の漏れを防ぐために，キャピラリ先端 にはシリコーンゴムなどがガスケットとして塗布されている。 変形しやすい材料をガスケットとして使用することが多いた め，ガスケットはそれを押し付ける荷重によって変形する。 微小液滴セルの直径は変形したガスケットの内径に等しいの で, 荷重やガスケットの材質を制御することでセル面積の再 現が比較的容易である。しかし, 荷重が不十分, 試料電極表 面が粗すぎる等のために，ガスケットと試料表面の間に溶液 が入り込むと試料表面ですき間腐食を発生することがある。 精密な測定のためにはガスケットを押し付ける荷重を精密に 制御することが必要である。さらに, 微小液滴セルに溶液を 導入する際，試料電極上に気泡を残さないようすることが必 要である。これらの操作は個々の試料表面部位に微小液滴セ ルを形成する毎に行う必要があるため, この型の微小液滴セ ルの試料表面の 2 次元的な走査はメニスカス型に比べて困難 である。 Mardare ら ${ }^{32)}$ は, ガスケット型微小液滴セルの走査 システムを開発して $100 \mu \mathrm{m}$ のスポットサイズで再現性良く 陽極酸化できることを報告している。彼ら ${ }^{33)}$ は，3D プリン 夕により作製した走査型微小液滴セルを陽極酸化に用い，そ の再現性の評価も報告した。3D プリンタを用いることで, 従来の機械加工では作製が困難であった形状の微小液滴セル も作製可能であるため, 今後, これまでにない微小液滴セル が発表される可能性を秘めている。しかし, 現時点で容易に 購入できる $3 \mathrm{D}$ プリンタにより作製できる微小液滴セルは,

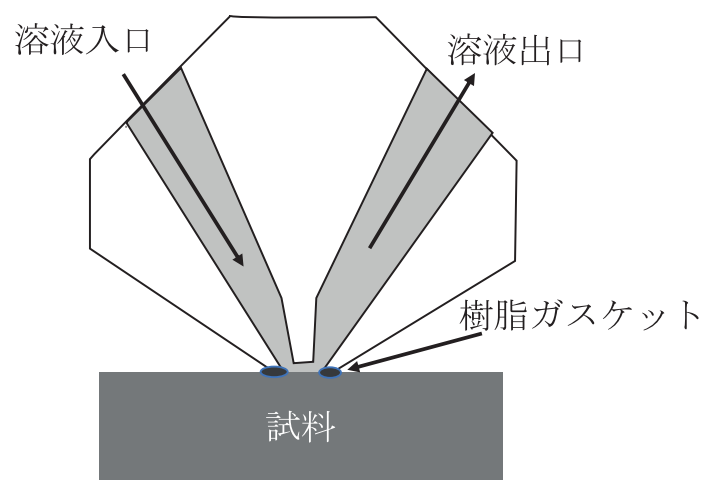

図 2 ガスケット型フローセルの模式図
既に報告されているキャピラリの径より径がかなり大きい。 メニスカス型は，図1(b)のようにキャピラリ管先端を試 料表面から一定の距離を隔てて配置する。キャピラリ管先端 と試料表面の間に電解質溶液の微小な液滴が形成でき, これ を微小液滴セルとする。電気化学測定や陽極酸化の対象とな るのは，液滴と接する試料表面である。試料とキャピラリ先 端の両表面上と接する電解質溶液の表面張力と溶液にかかる 重力の釣り合いにより液滴が保持され，正確な形状は両表面 に対する電解質溶液の濡れ性, キャピラリ管と試料表面の距 離および液滴の量に支配される。そのため, 図 1 (b)のよう にキャピラリ管の外側に薄い水膜が形成するものの, その直 径は使用するキャピラリ先端外径におおよそ等しくなる。液 滴の形成条件から, 微小液滴セル面積が変動しやすいため面 積を一定に保持することや正確に規定することは難しい。し かし，キャピラリ管先端が試料表面と非接触であることから 微小液滴セルを試料表面で 2 次元方向に走査しやすい特徵を 持っている。

\section{2 溶液フロー型微小液滴セル}

微小液滴セルの欠点は, めっきのように大電流が流れると溶 液組成が変化することが懸念されるため, どちらの構造におい ても溶液をフロー型にした微小液滴セルも開発されている。

Lohrengel らは，断面が $\theta$ 型のキャピラリ管を用いたガス ケット型微小液滴セルを開発し, 各々のチャンネルで溶液の 供給と排出を可能としている ${ }^{34)}$ 。Kollender ら ${ }^{35)}$ は図 2 のよ うなセルを $3 \mathrm{D}$ プリンタで作製し, 微小領域の電気化学と ICP-MS による溶液分析と組み合わせて研究を行っている。 メニスカス型については，伏見らが同軸 2 重管構造を有する 溶液フロー型微小液滴セル $(\mathrm{Sf}-\mathrm{MDC})$ を開発し, そのセルを 用いて局部的な腐食挙動の違いを測定している ${ }^{36)}$ 。著者ら も伏見の開発したセルを使用している。使用している，溶液 フロー型微小液滴セルの模式図を図 3 に示す。本セルのよう

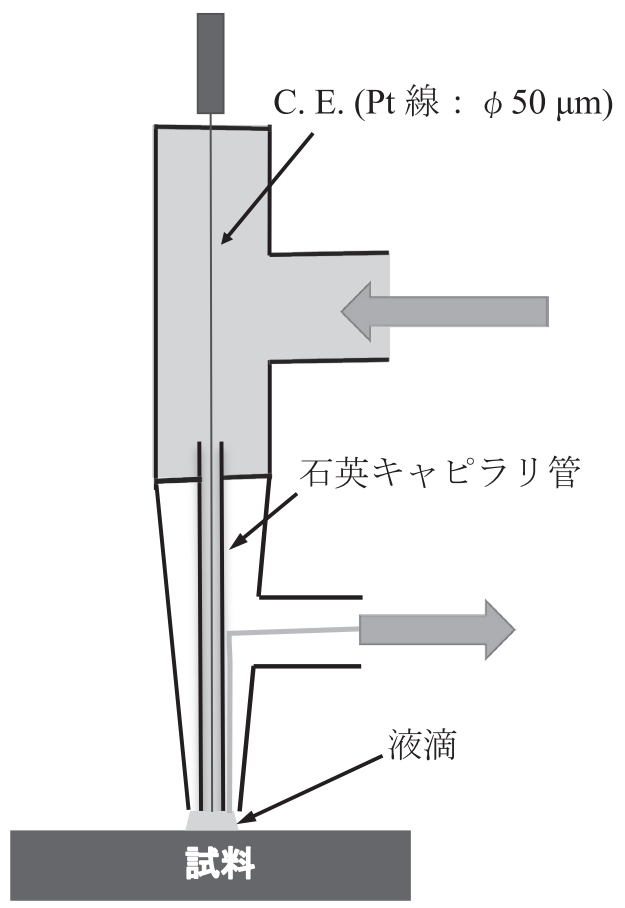

図 3 同軸 2 重管構造の微小液滴セル (Sf-MDC)の模式図 
に長いキャピラリ管を使用すると, その内部の溶液抵抗が大 きくなる。そのため, Pt 線 $(\phi 50 \mu \mathrm{m})$ を石英製キャピラリ管(内 径 $100 \mu \mathrm{m})$ の内部に挿入し, 試料電極と対極との距離を短くす ることで, 溶液抵抗を小さくしている。Sf-MDCを用いる電気 化学装置の模式図を図 4 に示す。送液ポンプで送られた電解質 溶液は上部から入り，石英製キャピラリ管の先端から出てくる。 外側の管を負圧にすることでキャピラリ管先端に液滴を形成で きる。図 4 のようにこの液滴を試料極に接触させることで 2 電 極式の電気化学微小液滴セルとして使用可能である。この微小

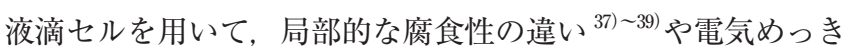
との組み合わせによる微細構造体の作製 ${ }^{40) ~ 42)}$, 局部陽極酸 化 ${ }^{43) \sim 45)}$ を行っている。

\section{Sf-MDC による陽極酸化}

以後, 同軸 2 重管構造を有する溶液フロー型微小液滴セル (Sf-MDC)による位置や形状を制御した陽極酸化について述 ベる。試料には, 高純度アルミニウム箔(99.99 mass\%Al, 厚 さ : $110 \mu \mathrm{m})$ を $1 \times 3 \mathrm{~cm}^{2}$ に切り出して用いた。前処理として, 高純度水および $\mathrm{CH}_{3} \mathrm{CH}_{2} \mathrm{OH}$ 中で $300 \mathrm{~s}$ 超音波洗浄を行った。 その後, $13.6 \mathrm{kmol} / \mathrm{m}^{3} \mathrm{CH}_{3} \mathrm{COOH}$ と $2.56 \mathrm{kmol} / \mathrm{m}^{3} \mathrm{HClO}_{4}$ 混 合 溶液中で定電位 $28 \mathrm{~V}$ で, $150 \mathrm{~s}$ 電解研磨を行った。電解研磨 後の試料は, 高純度水と $\mathrm{CH}_{3} \mathrm{COOH}_{3}$ で洗浄し, 空気中で乾 燥した。液滴の形成は, 図 3 の Sf-MDC 上部にある溶液流入 口よりポンプを用いて $0.22 \mathrm{kmol} / \mathrm{m}^{3}$ の $(\mathrm{COOH})_{2}$ を一定速度 で流し，下部にある溶液吸引口からアスピレータを用いて溶 液を吸引した。シリカキャピラリ先端 (図 3 下部) と試料の距 離を $20 \mu \mathrm{m}$ に保持することで, 液滴を試料と接触させた。 液滴が試料と接触した後, 試料と対極との間に $50 \mathrm{~V}$ の定電 圧を印加した。Sf-MDCによる局部陽極酸化の際, 試料とセ ルを相対的に移動させない(静止状態) と, ポーラス型皮膜の 形成に従って液滴周辺部の濡れ性が変化するため液滴が広が り, 目的の形状や厚さの皮膜を形成出来ない ${ }^{46)}$ 。そのため, 幅や形状を制御して皮膜を形成するためには, 試料とセルを 相対的に移動する必要がある。そのため, 陽極酸化の際, 試 料をXYZ ステージに上に置き(図 4), ステージを一定速度 で双方向に任意回数走査した。本稿の走査回数は, 1 往復の 走査を走査回数 2 回とした。試料温度は, ベルチェ素子によ り $323 \mathrm{~K}$ に保持した。

図 5 にSf-MDC を用いて定電圧で陽極酸化した際に測定さ れる電流の例を示す。走査速度は $2.0 \mu \mathrm{ms}^{-1}$, 走査回数は 10

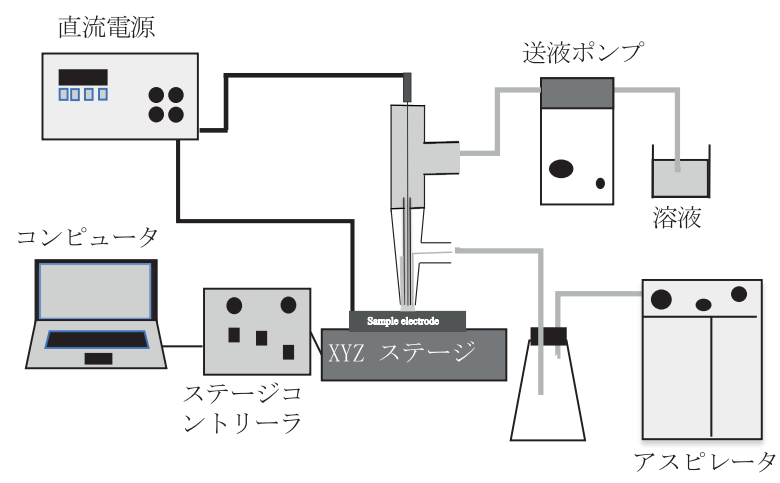

図 4 Sf-MDC を用いる電気化学装置の模式図
回である。なお，図中に一回の走査間隔を点線で示してある。 各回数毎の平均的な電流值は, 回数が増えるに従って徐々に 減少している。ここで測定される電流值は, 1 回の走査で形 成できる酸化物皮膜の厚さと相関がある。形成される皮膜厚

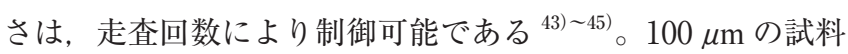
を貫通する孔を有する酸化物皮膜を形成するには, ここで述 べた条件で陽極酸化すると約 40 回の走査が必要である。

図 6 に走査速度 $4.4 \mu \mathrm{ms}^{-1}$ で陽極酸化した試料表面の(a) 光学顕微鏡写真と $(b)$ 走査型電子顕微鏡 $(S E M)$ 写真を示す。 図 6 (a)の中央の黒い部分が陽極酸化により形成した酸化物 皮膜である。図 6 (a) の酸化物皮膜を SEMにより観察した結 果を図 5 (b)に示す。規則正しい微細孔が観察でき, Sf-MDC

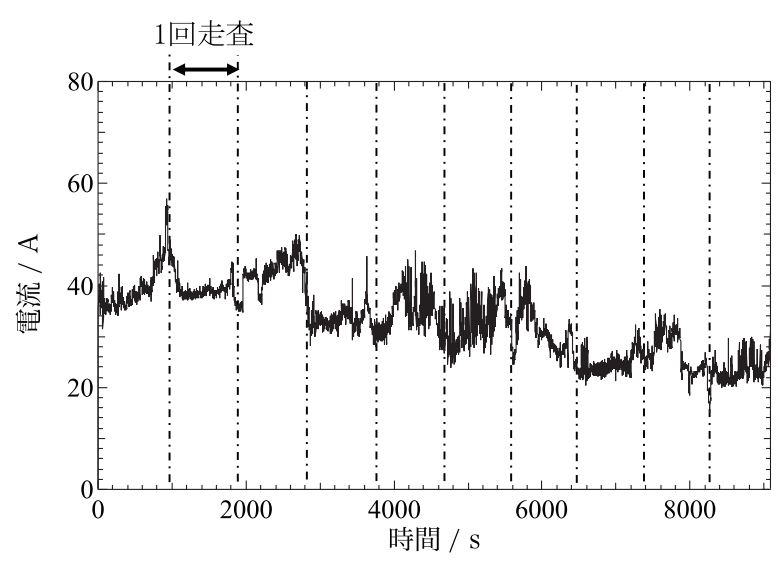

図 5 Sf-MDCによる陽極酸化中に測定される電流の例
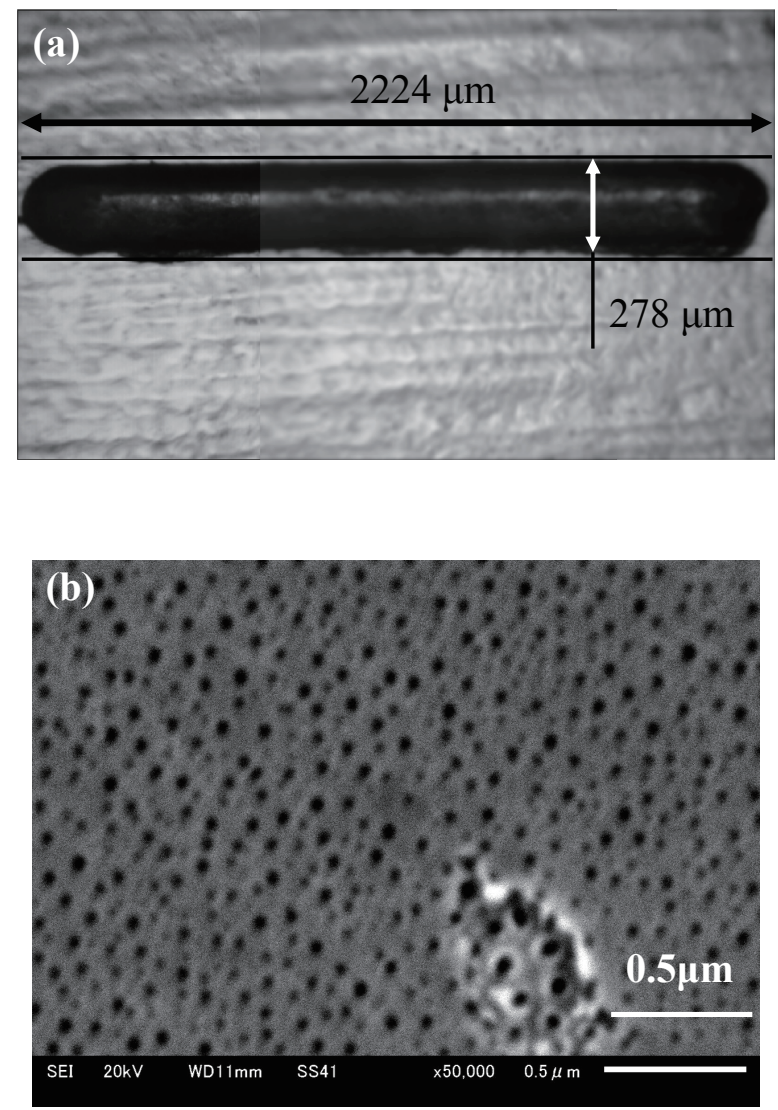

図 6 走查速度 $4.4 \mu \mathrm{ms}^{-1}$ で陽極酸化した試料表面の (a) 光学顕微鏡写真と (b) SEM 写真 

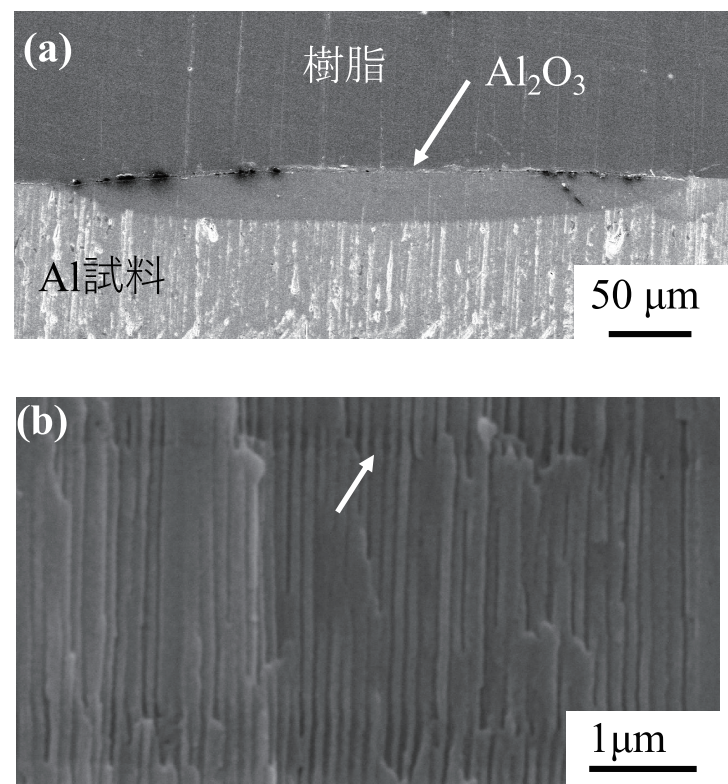

図 7 走查速度 $2.0 \mu \mathrm{ms}^{-1}$ で 10 回走査して形成した酸化物皮膜の (a) 断面 SEM 写真, (b) 酸化物皮膜の中心付近を拡大し た SEM 写真

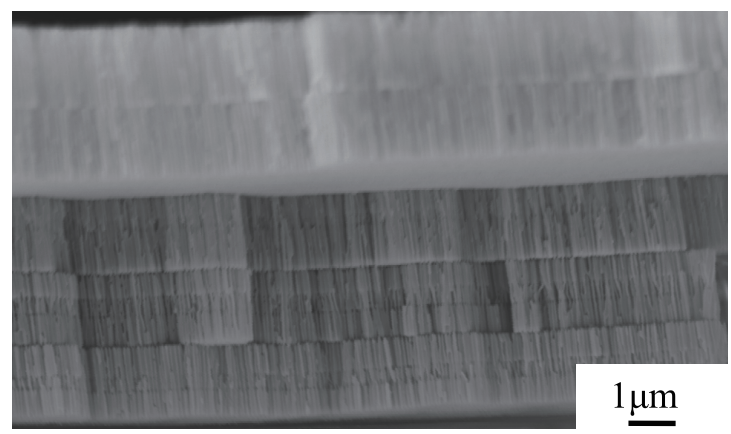

図 8 酸化物皮膜破断面の SEM 写真

を用いても通常と同様のポーラス型酸化物が形成可能である ことがわかる。

図 7 にSf-MDC を用いて走査速度 $2.0 \mu \mathrm{ms}^{-1}$ で形成した陽 極酸化皮膜断面のSEM 写真を示す。Sf-MDCを使用して試 料を走査させながらアノード酸化を行うと, 図 7 (a)のよう な凸レンズ形状の断面を有する皮膜が形成される。キャピラ リ先端に形成した液滴の試料と接する面の形状は円形である ため, 試料を走査すると液滴の接している時間が中心付近と 周囲で異なることになることが理由である。言い換えると， 液滴の中心部でアノード酸化時間が長時間になるため繰り返 し走査することで, 図 7 (a)のように中心部がその周囲より も酸化物皮膜が厚く成長し, 結果として断面が凸レンズ型に なる。図 7 (b) の断面からも規則正しい微細孔が観察できるが, 微細孔壁は直線 (図中矢印) ではない。Sf-MDCを用いると酸 化物皮膜は連続的に成長しないため ${ }^{44)}$, 図 8 に示すような 境開しやすい層状の断面構造を有する酸化物皮膜が形成する。

\section{1 局部陽極酸化の応用例}

形状や厚さを制御して形成して局部的に陽極酸化皮膜の形 成への応用例を示す。試料移動を制御することで，図 9 (a) のような形状の酸化物 (図中の白い部分)を形成可能である。 (a)

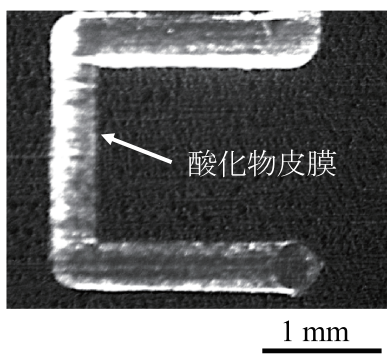

(b)

透過試験前
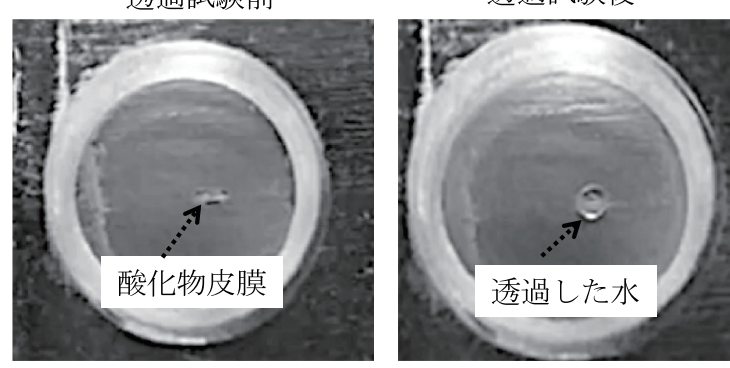

図 9

(a) Sf-MDCにより形状を制御して形成した酸化物皮膜の写真 と (b) 貫通型のポーラス型酸化物層による水透過試験の写真

これまで示したような局部的に形成したポーラス型酸化物皮 膜の応用としては, メンブレンフィルターや光学フィルター があげられる。メンブレンフィルターとして利用するために は，形成した酸化物皮膜底部に存在するバリヤー層を部分的 に溶解し，貫通孔を作製する必要がある。Sf-MDCによりア ノード酸化皮膜を形成し, その後の化学溶解によって貫通型 のポーラス型酸化物層を作製した。作製した貫通型のポーラ ス型酸化物層を透過試験用の治具に取り付け, 水の透過試験 を行った写真を図 9 （b）に示す。水は, 試料裏面よりシリン ジにより圧入した。透過試験前と後の写真から, 水がポーラ ス型酸化物層を透過していることがわかる。このことは, Sf-MDCによりアノード酸化皮膜を形成し, その後の化学溶 解により，貫通孔を有する酸化物層を形成できることを意味 している。

\section{4.おわりに}

本稿では, 微小液滴セルについての解説とその応用例とし て著者らが研究している同軸 2 重管構造をもつ溶液フロー型 微小電気化学セルを用いる局部陽極酸化について述べた。微 小液滴セルを用いると被覆せずに，微小領域の陽極酸化のよ うな電気化学反応を実現することが可能である。本稿が，微 小液滴セルに興味をもつきっかけとなれば幸いである。

(Received October 15, 2018)

\section{文献}

1 ) R. S. Alwitt ; J. Electrochem. Soc., 114, 843 (1967)

2 ) 高橋英明, 斎藤芳一, 永山政一; 金属表面技術, 33, 225 (1982).

3 ）清水健一,小林賢三, 西部春仁; 軽金属, 35, 533 (1985).

4 ）加藤正義; 金属表面技術, 39, 420 (1988).

5 ）小林賢三,清水健一; 表面技術, 40,703 (1989).

6 ）渡辺恵司，坂入正敏，高橋英明，平井伸治 ; 表面技術, 54,235 
(2003).

7 ) 和田智恵子, 阿相英孝, 小野幸子; Electrochemistry, 75, 145 (2005).

8 ) F. Evangelistia, M. Stiefel, O. Guseva, R. P. Nia, R. Hauert, E. Hack, L. P. H. Jeurgens, F. Ambrosio, A. Pasquarello, P. Schmutz, C. Cancellieri ; Electrochim. Acta, 224, 503 (2017).

9 ）神崎信義, 島谷涼一, 高橋 寛, 徳外弘幸 ; 表面技術, 41, 808 (1990).

10）永山政一,高橋英明, 甲田 満; 金属表面技術, 30, 438 (1979).

11）海老原健, 高橋英明, 永山政一; 金属表面技術, 33, 156 (1982).

12）海老原健, 高橋英明, 永山政一; 金属表面技術, 34, 548 (1983).

13）海老原健, 高橋英明, 永山政一; 金属表面技術, 35, 205 (1984).

14) H. Masuda, K. Fukuda ; Science, 268, 1466 (1995).

15) G. T. Thompson; Thin Solid Films, 297, 192 (1997).

16) H. Masuda, F. Hasegawa, S. Ono ; J. Electorchem. Soc., 144, L127 (1997).

17) S. Ono, M. Saito, M. Ishiguro, H. Asoh ; J. Electrochem. Soc., 158, B473 (2004)

18) J. H. Yuan, W. Chen, R. J. Hui, Y. L. Hu, X. H. Xia ; Electrochim. Acta, 51, 4589 (2006).

19）高橋英明; 表面技術, 62, 324 (2011).

20) T. Yanagishita, H. Masuda ; Electrochim. Acta, 184, 80 (2015).

21) H. Asoh, T. Masuda, S. Ono ; ECS Transation, 69, 255 (2015).

22) A. Mozalev, M. Bendova, F. G-Guirado, Z. Pytlicek, E. Llobet ; J. Mater. Chem. A, 4, 8219 (2016)

23) A. Mozalev, M. Bendova, R. M. Vazquez, Z. Pytlicek, E. Llobet, J. Hubalek; Sens. Actuators B, 229, 587 (2016).

24) L. Wen, R. Xu, Y. Mi, Y Lei ; Nature Nanotech., 12, 244 (2017).

25) H. Ikeda, M. Iwai, D. Nakajima, T. Kikuchi, S. Natsui, N. Sakaguchi, R. Suzuki ; App. Surf. Sci., 465, 747 (2019).

26）原 正雄, 平野愛弓 ; 分析化学, 51,1121 (2002).

27) H. S. Isaacs, B. Vyas ; Electrochemical Corrosion Testing, p.3 (ASTM, STP 727, 1981).
28）伏見公志, 坂入正敏, 幅崎浩樹 ; 表面技術, 59, 863 (2008).

29) T. Otsuka, A. Nishikata, M. Sakairi, K. Fushimi ; Springer Briefs in Molecular Science, Electrochemistry for Corrosion Fundamentals -Chapter 6 (Springer Nature Singapore Pte Ltd., Singapore 2018).

30) H. Böhni, T. Suter, A. Schreyer ; Electrochim. Acta, 10, 1361 (1995).

31) M. M. Lohrengel ; Electrochim. Acta, 42, 3265 (1997).

32) A. I. Mardare, A. W. Hassel ; Rev. Sci. Instr., 80, 046106 (2009).

33) A. I. Mardare, C. C. Mardare, A. W. Hassel ; J. Solid. State Elecrochem., 22, 869 (2018).

34) M. M. Lohrengel, I. Klüppel, C. Rosenkranz, H. Bettermann, J. W. Schultze ; Electrochim. Acta, 48, 3203 (2003).

35) J. P. Kollender, M. Voith, S. Schneiderbauer, A. I. Mardare, A. W. Hassel ; J. Electroanal. Chem., 740, 53 (2015).

36) K. Fushimi, S. Yamamoto, R. Ozaki, H. Habazaki ; Electrochim. Acta, 53, 2529 (2008).

37）坂入正敏，村田拓哉，菊地竜也，伏見公志；防錆管理， 53,361 (2009).

38) S. Hashizume, T. Nakayama, M. Sakairi, K. Fushimi ; Zairyo-toKankyo, 60, 196 (2011).

39) M. Sakairi, T. Murata, T. Kikuchi, K. Fushimi ; ISIJ Int., 50, 1466 (2010)

40) M. Sakairi, F. Sato, Y. Goto, K. Fushimi, T. Kikuchi, H. Takahashi ; Electrochim. Acta, 54, 616 (2008)

41) M. Sakairi, Y. Goto, T. Kikuchi, K. Fushimi, H. Takahashi ; Electrochemistry, 78, 118 (2010).

42）坂入正敏，後藤良仁，菊地竜也，伏見公志；表面技術， 62,511 (2011).

43）山口智也, 坂入正敏; 表面技術, 65, 385 (2014).

44) M. Sakairi, F. Nishino, R. Itzinger ; Sur. Inter. Anal., 48, 921 (2016).

45）松本敏幸, 坂入正敏; 軽金属, 68, 401 (2018).

46) T. Murata, Y. Goto, M. Sakairi, K. Fushimi, T. Kikuchi ; ECS Trans., 33, 57 (2011). 